\title{
Konsep Kapitalisme
}

\section{Erwin Mustaan 90100118091}

Kapital berasal dari kata Latin caput yang berarti kepala, sedangkan kata ism yang meng ekor pada derivasi sebagai paham Ekonomi. Jadi kapitalisme adalah modal isme, suatu paham ekonomi yang berdasaerkan modal. Kapitalisme juga diartikan sebagai sistem ekonomi dimana barang dan jasa diperjual belikan di pasar dan barang modal adalah milik entitas-entitas non- Negara dari unit terkecil hingga global. Eko Prasetyo menjelaskan bahwa Adam Smith adalah peletak dasar pemikiran kapitalisme yang menjelaskan bekerjanya hukum pasar atas dasar dorongan kepentingan-kepentingan oribadi karena kompetisi dan kekuatan individualism dalam menciptakan keteraturan ekonomi. Sedangkan Salah satu ciri utama kapitalisme adalah kebebasan individual dan analisis harga dan mekanisme pasar dalam perspektif Islam. Oleh Friedman kebebasan ini di jabarkan sebagai kebebbasan ekonomi dan kebebasan politik. Menurutnya kebebasan ekonomi adalah syarat mutlak kebebasan politik.

Secara umum Kapitalisme dapat dibedakan dalam dua bentukyaitu kapitalisme klasik dan modern. Adapun ciri kapitalisme secara murni yakni ( pemilikan dan kontral atas instrument produksi, kegiatan ekonomi diarahkab bagi pembentukan laba, tersedianya sistem pasar yang mengatur semua kegiatan, perolehan laba oleh pemilik modal serta peneydiaan tenaga kerja oleh buruh yang bertindak sebagai agen bebas). Sedangkan ciri kapitalisme Moderen meliputi ( produk untuk di jual bukan untuk di konsumsi sendiri, pasar sebagai sarana kerja jual beli dan upah sebagai kontrak, uang sebagai alat tukar menukar serta pengambilan keputusan dutangan pemilik modal dan persaingan bebas di antara pemilik kapital.

Konsep kapitalisme branggapan bahwa di dalam metodenya ada desiminasi pemasukan dan pembagian harta yang menyeluruh dan fire, tetapi sistem tersebut tanpa disertai penyeleksi, serta pemenuhan kemauan tidak pada tempatnya, pemsukan yang pada akhirnya menjadi tak terdistribusikan secara menyeluruh. 
Sistem kapitalisme yang ada sampai era saat ini adalah konsep kapitalisme yang sudah berubah bentuk, maka dari faktor tersebut konsep kapitalisme bisa dikatakan sebagai sebuah pemikiran cemerlang dikarenakan masih bisa membenahi dirinya untuk memperbaiki kekeliruan premis yang telah dilakukannya sendiir. 


\section{Daftar Pustaka}

Abu Bakar,2014.’Paradigma ekonomi Islam Dan Ekonomi Kapitalis”,Volume 1,Nomor 2, Oktober

Rosyid Zaiful Moh,2019 “Kapitalisme Pendidikan Islam (Antara Kompetisi dan Keadilan)” Jurnal Pendidikan,Vol.2,No.1,hlm 166.

Hasan Zainol,2020. “Analisis Terhadap Pemikiran Ekonomi Kapitalisme Adam Smith” Jurnal Ekonomi dan Hukum Islam, Vol,4 No1, April.

H. Idris Parakkasi dan Kamiruddin, 2018 “ Analisis harga dan mekanisme pasar dalam perspektif Ekonomi islam”,Jurnal Laa Masyir,Vol.5,No.1. 